\title{
With a little help from my friends: ministerial alignment and public spending composition in parliamentary democracies
}

\section{Abel Bojar}

To cite this article: Abel Bojar (2019) With a little help from my friends: ministerial alignment and public spending composition in parliamentary democracies, Political Research Exchange, 1:1, 1-21, DOI: 10.1080/2474736X.2019.1632674

To link to this article: https://doi.org/10.1080/2474736X.2019.1632674
(c) 2019 The Author(s). Published by Informa UK Limited, trading as Taylor \& Francis Group

曲 Published online: 29 Jul 2019.

III Article views: 205

View Crossmark data $[\pi$

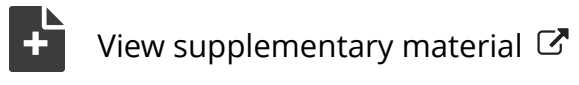

Submit your article to this journal

Q View related articles $\complement$

7 Citing articles: 1 View citing articles 5 


\title{
With a little help from my friends: ministerial alignment and public spending composition in parliamentary democracies
}

\author{
Abel Bojar \\ European University Institute, Florence, Italy
}

\begin{abstract}
The determinants of public spending composition have been studied from three broad perspectives in the scholarly literature: functional economic pressures, institutional constraints and partypolitical determinants. This article engages with the third perspective by placing intra-governmental dynamics in the centre of the analysis. Building on the portfolio allocation approach in the coalition formation literature and the common pool perspective in public budgeting, I theorize that spending ministers with party-political backing from the prime minister or the finance minister are in a privileged position to obtain extra funding for their policy jurisdictions compared to their colleagues without such support or without any partisan affiliation (non-partisan ministers). Via a system of equations on six spending categories using seemingly unrelated regressions as well as Prais-Winsten panel regressions on a sample of 32 parliamentary democracies over two decades, I offer mixed evidence for the impact of partypolitical alignment. While the relative share of four of the six budget categories systematically increases under the partypolitical alignment of the prime minister, the impact of finance minister alignment is only significant for the economic budget.
\end{abstract}

\section{ARTICLE HISTORY}

Received 24 September 2018 Accepted 12 June 2019

\section{KEYWORDS}

Budgeting; public spending; portfolio allocation; cabinet ministers; spending allocation

\section{Introduction}

If the study of politics is best conceptualized by the time-tested Lasswell (1936) catchphrase of 'who gets what, when and how', investigating the determinants of public spending composition should be one of the most relevant avenues of inquiry for political science scholarship. Since the birth of the modern 'tax state' and its subsequent transformation into the 'debt state' (Streeck 2014), an increasing amount of fiscal resources have been channelled from current and future taxpayers to recipients of welfare programs and beneficiaries of public goods and services. In most advanced capitalist democracies, around half of GDP passes through government coffers every year. Decisions on who gets what share of this pie and who gets favoured at the expense of whom have great potentials to fuel new political conflicts, restructure existing ones and ultimately decide the electoral fate of ministers, parties and governments responsible for the spending mix. 
Yet, despite the large body of literature addressing this issue, we lack a coherent account of the main drivers of spending shares across different budgetary categories. This article aims to take an important step in that direction by highlighting the role of political agency in the budget process. By building on two influential literatures on intra-governmental dynamics - the portfolio allocation model (Laver and Shepsle 1990) and the common pool resource approach (Vonhagen and Harden 1995), respectively - I highlight the crucial role of party-political alignment between governmental actors as an important predictor of spending composition in parliamentary democracies. The main argument I put forward and test in a panel of 32 parliamentary democracies over more than two decades is that spending ministers with the same party-political background as the prime minister and the finance minister are systematically privileged in the annual allocation of budgetary resources compared to ministers delegated by coalition partners and their non-partisan colleagues.

This government-centred explanation on spending outcomes does not sit in an unchartered territory, however. The extant literature on public spending composition that I review in the next section has provided a rich empirical arsenal to build on. The economic literature has made important contributions by highlighting some of the structural conditions - globalization, overall fiscal constraints, demography, etc. - that create various sources of social demands on different types of budgetary resources. The institutional perspective, by contrast, has zoomed in on the constitutional and legislative environment that shapes the incentives and strategic flexibility of the main political players to steer spending composition towards their political objectives. Thirdly, an important group of political accounts has stressed the role of ideology of collective actors as well as the personal backgrounds of the political elites as predictors of budget composition.

In this article I shall not aim to provide a definitive confirmation of these findings, nor shall I aim to call their validity into question. Instead, the main argument of this study is that the party-political aspect of intra-governmental dynamics merits further analysis because of two important shortcomings of the existing literature. First, much of the evidence provided is concerned with slowly changing phenomena, such as functional economic pressures and macro-political institutions. Their explanatory power may be strong in the long run, but they are hard to square with some of the short-term swings that one can observe in spending composition over the timeframe that this article addresses (19952017). ${ }^{1}$ Second, much of the empirical literature all too often conceptualizes governments as monolithic benevolent planners that somewhat mechanistically respond to the underlying demands of their constituencies without taking stock of other, self-serving motives that may shape their behaviour. This latter point is of course not entirely new in the long history of political thought; the origins of the public choice school in the context of budgeting (Niskanen 1971; Tullock et al. 2002) lie in this very premise. However, an explicit incorporation of the different and often conflicting incentives driving ministers' spending preferences offers valuable contributions to our understanding of the political economy of budgeting. Therefore, I shall offer an exploratory analysis of the impact of co-partisanship in government coalitions by building on the central idea of preference divergence between spending ministers and the main players - the finance minister and the prime minister - in the budget process.

Figure 1 offers a quick visual summary of the main explanandum. The plots provide a visual snapshot of country-specific spending shares of six COFOG $^{2}$ categories over the 


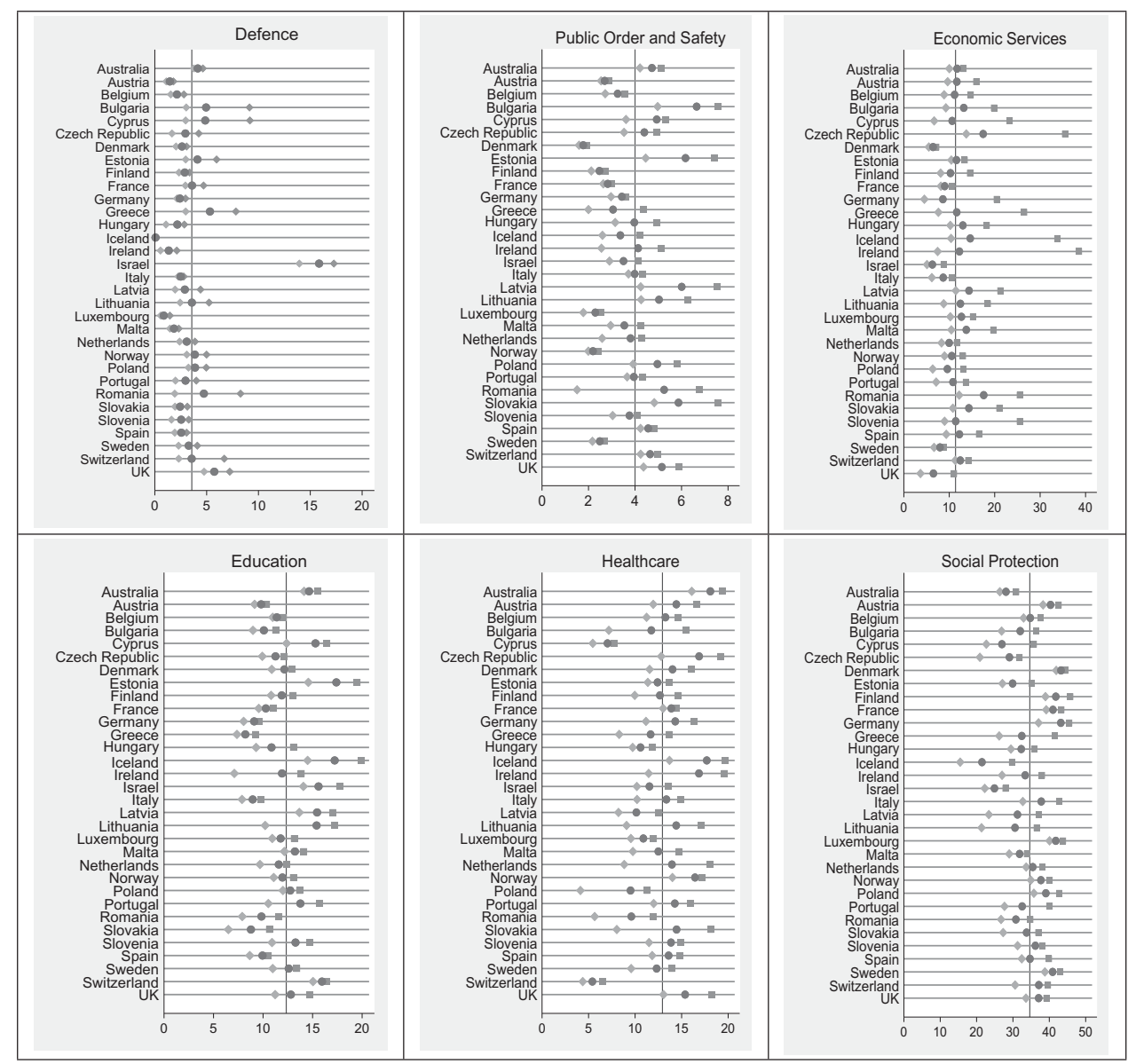

Figure 1. Spending shares of six COFOG categories in 32 countries between 1995 and 2017 (\% of total government spending). Vertical line: sample mean; grey circle: country mean; grey squares: country minima and maxima. Source: OECD, Eurostat, own calculations.

study period. The light grey rectangles mark the country-specific minima and maxima while the dark grey circles show the country averages. The vertical line cutting across the graphs marks the overall sample average. All data are expressed in \% of overall general government spending.

In any given spending category, the width of the country-specific ranges reveals that significant within-country variation occurred over a relatively limited time-span of two decades. Examples of large variation include the defense budget in Cyprus, spending on public order and safety in Latvia, economic services in the Czech Republic, and healthcare in Ireland. It is rather implausible to attribute these large swings to changes in the structural economic conditions or macro-political institutions. The cross-country patterns also seem hard to reconcile with some of the existing accounts, especially when one looks at some selected pairwise comparisons. In other words, comparing countryspecific averages between countries with similar institutional structures (forms of government, electoral and party systems, degree of federalism, welfare and production regimes, 
etc.) leaves some of the large differences unexplained. For instance, how does one account for the relatively large difference in healthcare spending between Latvia and Lithuania, or the difference between spending on economic affairs between Denmark and Finland when these country-pairs largely resemble in their institutional make-up and the prevailing economic conditions and structures? These over-time and crosscountry differences highlight the need to turn to short-term governmental dynamics for an answer.

After outlining the main approaches in the extant empirical literature in greater detail in the next section, I proceed to inquire what the portfolio allocation and the common pool resource literature can contribute to our conceptualization of public spending composition. I then outline the data and the empirical strategy. Finally, the main empirical findings are presented, complemented by robustness checks and extensions before I conclude.

\section{Structure, institutions or agency? Drivers of public spending composition}

The role of structural conditions and constraints prevailing in (post)-industrial societies has long been a prime candidate in accounting for the growth of the public sector (Adsera and Boix 2002; Swank 1988). Accordingly, a natural point of departure in the political economy literature is specifying the structural conditions that help explain not just the size, but also the composition of the public budgets.

Unsurprisingly, globalization stood out as one of the most influential drivers in these structural accounts (see Gemmell et al. 2008 for the role of FDI, Mahdavi 2004 for external debt and Dreher et al. 2008 for other metrics of trade and financial openness). Likewise, overall fiscal constraints have been highlighted as an additional factor determining the spending mix (Castro 2017; Sanz 2011). A third aspect of structural constraints that exert functional pressures on spending composition concerns demography via aging (Sanz and Velazquez 2007) and urbanization of modern economies (Agthe, Billings, and Marchand 1996).

From a political science perspective, however, it would be rather naïve to presume that functional pressures automatically translate into an optimal change in the spending mix, as if driven by the invisible hand of social demand and political supply. Such critique of structural determinism is widely recognized by institutionalist scholars who see macro-political institutions both as constraints and as shapers of governmental actors' incentives. From the former perspective, Tsebelis and Chang (2004) use the constellation veto players as well as the ideological distance between them to predict changes in budget composition in a multidimensional space. Another example of the view of institutions as constraints is offered by the vast literature on fiscal rules. Tsai (2014), for instance shows that carryover rules in American states condition the changes in states' budget composition in the run-up to gubernatorial elections.

Alternatively, institutions can be conceptualized as strategic opportunities shaping the incentive of governmental actors to further their political objectives. One prominent contribution from this angle is Milesi-Ferretti et al.'s seminal article (2002) that distinguishes between geographically targetable spending (such as government purchases of goods and services) and broad-based transfers and argues that electoral systems condition which types of spending would be preferred by re-election seeking incumbents. In a 
similar spirit, Breunig and Busemeyer (2012) distinguish between discretionary and entitlement spending and show how the two types of spending categories are affected differently in times of austerity in different electoral systems.

Despite these important findings, by their very nature macro-political institutions change very rarely and hence their explanatory power in accounting for large withincountry changes demonstrated earlier is inherently limited. This consideration has prompted a group of scholars to zoom in the role of government itself, as distinct from state structures discussed above, for an answer. After all, elections and government changes bring a new set of players to decision-making positions with an opportunity to act upon their first preferences subject to institutional constraints. The role of government ideology has accordingly been shown to impact on different budgetary categories. Potrafke (2011) shows that government ideology has a weak influence on budget composition with left-wing governments more likely to channel resources to general public services and education. In the American context, a recent contribution of Adolph, Breuning, and Koski (Forthcoming) demonstrates on the state level that partisan governments strategically gear the spending mix to their own priorities by raiding government programs favoured by their political opponents. When ideology, strictly understood in partisan terms, is replaced in the empirical studies by the attention that parties devote to certain budgetary items in their manifestos, the effects are considerably stronger. In this vein, Breunig (2011) demonstrates that attention shifts lead to large changes in budget composition whereas Brauninger (2005) shows that the relative salience of issues in parties' manifestos is a strong predictor of the relative share of social and economic types of budget outlays. By focusing on spending on public order and safety policies (police forces, prisons, etc.), Wenzelburger (2015) also finds a strong influence of government ideology, as measured by parties' manifestos, on budget outcomes. The general thrust of the partisanship literature, therefore, is that the programmatic priorities of parties are a stronger predictor of budget composition outcomes than their partisan labels and their broad ideological affiliation.

However, certain individuals at the top echelons of the decision-making hierarchy may have an independent influence over budget outcomes, on top of what their parties' preferences may normally dictate. On a general level, Brender and Drazen (2013) show that leadership changes (replacement of prime ministers in parliamentary and presidents in presidential systems) lead to significant changes in budget composition. With a narrower focus on certain budget items, Hayo and Neumeier (2012) emphasizes the role of prime ministers' professional and personal background in the context of the German Landers: those from lower socioeconomic status tend to privilege spending types that have an equalizing effect, namely healthcare and social protection. If the personal characteristics of political leaders seem to matter for budgetary outcomes, a natural extension of the analytical enquiry is from the top level to the lower echelons of policy-making.

In fact, a related body of literature has studied the role of individual spending ministers in cabinet formation and policy output. The idea that heading spending ministries is a key objective of office-seeking political parties has a clear intuitive appeal. Empirically, one of the most robust relationships in political science that lays a well-deserved claim on its status implied by its name is Gamson's law (Browne and Franklin 1973): parties tend to occupy a share of ministerial portfolios in direct proportion to their seat shares (and in PR systems to their electoral strength) in parliament. It is also fairly well established that 
parties also place a great emphasis on the type of portfolios they bargain for at the stage of coalition formation (Back, Debus, and Dumont 2011; Warwick and Druckman 2006): they are more likely to occupy ministries that they emphasize in their election manifestos or reveal to prefer via expert interviews (see also Raabe and Linhart 2014 for salience measures of ministerial portfolios in the German context).

Though the extent to which these ministers enjoy autonomous policy-making powers against the various levers of coalition partners has been subject to a long-standing debate (Carroll and Cox 2012; Dunleavy and Bastow 2001; Laver and Shepsle 1990; Thies 2001; Warwick 1999), there is a growing body of literature that examines the ministerial impact on policy output. For instance, Martin and Vanberg (2014) analyse the amendments to proposed bills and show that their final version reflects coalition compromises. Giannetti and Laver (2005) focus on cabinet ministers' parliamentary speeches during the Prodi government in Italy over the period of 1996-1997 and finds that they are strong predictors of departments' spending allocations. Alexiadou (2015) in turn emphasizes the role of ministers' personal background and empirically shows that they are related to welfare policy output under their jurisdictions. In particular, the author's distinction between partisan heavyweights, loyalists and ideologues serves to illuminate the crucial role of ministers' party-political position in the cabinet in predicting policy outcomes.

Of the multiplicity of factors that determine spending ministers' policy leverage, a shared view in the coalition literature concerns the relative bargaining power between coalition partners. Though cabinets in parliamentary systems vary a lot on the collegialhierarchical spectrum of policy-making (Alesina and Perotti 1999), two key players are universally viewed as first among equals. Of particular importance as the leading voice of formateur parties in coalitions, the prime minister has special agenda-setting powers in determining spending priorities at the time of coalition formation and in response to new problem pressures that arise from year to year. While she is politically accountable to all constituencies that benefit from spending programs, the prime minister also has partisan goals in mind when navigating the trade-off between spending demands under hard budget constraints. These partisan goals in turn likely boil down to considerations of patronage opportunities that the control of spending ministries via their co-partisan colleagues entail. When having to choose between demands by a spending minister delegated by a coalition partner and those made by a partisan colleague, the prime minister is likely to favour the latter as it confers both personal (as the prime minister ultimately responsible for all governmental decisions) and partisan (typically as head of her party eyeing for the next elections) rewards on her. By contrast, bowing to demands of a minister delegated by a different party carries the risk of allowing a potential partisan rival to claim credit for the extra resources accruing to her department and foregoing patronage opportunities among the prime minister's party's constituency. The implication for budget allocation is clear: spending ministers delegated by the senior coalition party headed by the prime minister have, ceteris paribus, a head start when it comes to budget appropriations vis a vis their cabinet colleagues who are delegated by rival parties (or are non-partisan members of the cabinet).

In addition to the prime minister, an equally influential player in the budget process is the minister of finance (Hallerberg et al. 2009; Jochimsen and Thomasius 2014). Typically conceptualizing the finance minister as the guardian of budget discipline whose primary objective is to constrain the spending demands of his cabinet colleagues, another 
influential body of literature has modelled the total budget as an outcome of a complex interaction between spending ministries and the finance minister who bargain over a common pool of fiscal resources (Velasco 2000; Vonhagen and Harden 1995). ${ }^{3}$ In the simplest formulation of this model, each player reaps the full benefits of constituency-specific spending but bears only a fraction $1 / N$ of the costs implied by the extra tax and/or debt burden that is spread over the whole population, where $N$ is the number of relevant players. The more numerous the players are, the weaker is the position of the finance minister to stand up against such spending demands unless aided by a set of budgetary institutions created as a counterweight to these pernicious dynamics (Hallerberg et al. 2009; Poterba and von Hagen 1999).

For the purposes of drawing predictions for budget composition, it is crucial to disentangle the specific nature of $\mathrm{N}$ in the common pool perspective. In a partisan-free setting, it is the size of the cabinet that it is mostly relevant: the larger (the more fragmented) the cabinet is, the more severe the spending pressure becomes leading to larger total outlays (Perotti and Kontopoulos 2002; Schaltegger and Feld 2009). More realistically, however, budget negotiation takes place in a partisan setting. In addition to the intrinsic benefit that greater fiscal resources bring in the form of pork-barrel and patronage opportunities as well as personal prestige (Niskanen 1971; Raabe and Linhart 2014), participants at budget negotiation are also likely to have partisan motives in mind with crucial implications for the role of the finance minister. In particular, the conflictual relationship that characterizes the link between the finance minister, responsible for budget discipline, and spending ministers who fail to internalize the costs of excessive spending and thus push for ever greater funding for their departments, is expected to depend on their party-political background. If the players are conceptualized as parties (Bawn and Rosenbluth 2006; Wehner 2010) rather than individual ministers, the calculus of the finance minister is altered. Her motives to rein in departmental spending are now tampered by her partisan goals to channel higher spending shares to their co-partisan colleagues at the expense of coalition partners. Tentative evidence for this logic is provided by Herzog and Mikhaylov (2014) who show that ministers' proximity to the finance minister, as measured by the content of their contributions in budget debates, appears as a strong predictor of their departments' budget allocations in the Irish context.

In essence, while the coalition formation literature underlines the role of formateur parties, and therefore the prime minister as the key actor in constraining departmentspecific incentives of spending ministers for higher spending, the common pool perspective highlights the finance minister as the guardian of budget discipline and as the key to department-specific spending constraints. Crucially, one can infer from both perspectives that shared party-political background is a crucial mediating factor in the budgeting calculus by aligning incentives between the key players and the spending ministers for higher budget shares at the expense of ministries led by coalition partners or non-partisan colleagues.

A number of objections can be raised to this reasoning at this point. First, one needs to acknowledge the role of procedural budgetary institutions (Hallerberg et al. 2009, 2) and fiscal rules (Poterba 1996; Rose 2006) that constrain the spending power of individual ministers as well as the agenda-setting and oversight powers of the two key players. I contend, however, that given these institutional constraints, the party-political alignment between the key players continues to matter on the margin. For instance, even if a constitutionally 
mandated fiscal rule sets a ceiling on the size of the overall budget, the spending shares accruing to the specific departments, which is my focus, is expected to depend on partisan alignment patterns. In other words, the logic of ministerial alignment outlined above is largely independent of overall fiscal constraints.

Likewise, in coalition systems, parties typically commit to long-run spending targets in their coalition agreements (Back, Muller, and Nyblade 2017; Indiradason and Kristinsson 2013; Tobrjorn, Muller, and Strom 2005). However, these agreements typically set multiyear constraints and leave significant room for manoeuvre for ministerial agency in terms of getting a better deal from year-to-year corrections to the fiscal path in response to unforeseen developments. For instance, while the overall spending-allocations over the government's term may be fixed in the initial agreement, the prime minister and the finance minister have a degree of discretion on how they respond to fiscal shocks over the cycle. Which ministers get sheltered from an unforeseen fiscal squeeze, for instance, is likely to depend on their party-political alignment following the logic outlined above.

Finally, note that these expectations are largely 'partisan-blind' to the extent that the impact of ministerial alignment is expected to hold on the margin, regardless of whether it occurs on the left (social-democratic) or right (conservative) end of the political spectrum. While I incorporate the potential role of ideology in the empirical analysis in a variety of ways - see the data and methods section below - the expectations derive from the patronage opportunities that extra spending entails rather than broad ideological motives on the overall size of the government and the role of the state in the economy. In other words, I expect these motives to be present after taking into account (controlling for) the potential role of ideological determinants of budget size and composition.

This article thus focuses on these party-political alignment patterns between spending ministers on the one hand and the two key players on the other hand and proceeds to test two empirical hypotheses separately:

H1: Party-political alignment between the prime minister and a spending minister increases the budget share accruing to the spending minister's department.

$\mathrm{H} 2$ : Party-political alignment between the finance minister and a spending minister increases the budget share accruing to the spending minister's department.

\section{Data, measurement, estimation}

This article tests the two hypotheses in a sample of 32 parliamentary democracies over the period of 1990-2017 (see Table A1 in the Appendix for details). I restrict the sample to parliamentary systems because the constellation of actors under division of powers in presidential regimes implies a fundamentally different - and somewhat more complex - sort of political logic behind budgetary allocations. The temporal dimension is driven by data limitations imposed by functional classification of government spending. The current version of COFOG has been derived by the UN's statistical division from the system of national accounts (OECD 2011) and is available for OECD and EU member states (OECD 2019; Eurostat 2019). I focus on the six COFOG categories that are numerically important (make up more than $3 \%$ of total spending on average) and can be clearly matched with a spending ministry with the relevant policy jurisdiction. The six categories with the relevant 
ministries are defense (minister of defense), public order and safety (minister of the interior), economic affairs (minister of the economy ${ }^{4}$ ), education (minister of education), health (minister of health) and social protection (minister of welfare/social affairs). The party-political background of ministers comes from an online database compiled by Lars Sonntag ${ }^{5}$ which I cross-checked with some of the cabinets' Wikipedia pages as well as with the Party Systems and Government Observatory database (Bertoa 2019) for reliability.

For each budgetary item, I create two department-specific indicator variables that take on the value 1 if the minister overseeing that department is delegated by the same party as the prime minister or the finance minister, respectively and 0 otherwise. Lacking a priori theoretical expectations on the difference between the ministers being delegated by separate parties and any of the three key players (the spending minister, the prime minister and the finance minister) being a non-partisan politician, we assign the value 0 in the indicator variables to all these scenarios and estimate the impact of the ministerial alignment compared to this reference category. The frequency distribution of alignment-types for each of the six ministries is shown in Table A2 in the Appendix.

The dependent variable of the study is the budgetary share of the respective COFOG categories. All shares are expressed as a percentage of total general government spending (ie bounded by 0 and 100) as our primary interest is how resources are allocated subject to a budget constraint, a reasonable approximation for a period of general scarcity in fiscal resources. In other words, the aim is to measure spending shares in a way that directly takes into account the trade-off between them, ie their zero-sum nature.

The empirical models control for a number of variables deemed relevant by the empirical literature on budget composition. Following the structure of the literature overview, I divide up these controls into three clusters: structural, institutional and political. In particular, I use controls that have either been singled out by the literature as relevant for the entire budget composition or can be directly related to some of the particular budgetary categories by theoretical considerations. For instance, while a measure for fiscal constraint and globalization is included for all equations, a demographic variable is only introduced for healthcare, social protection and education.

Table A3 in the Online Appendix summarizes the controls, together with their source, that enter the spending share-specific models. Apart from the overall criteria outlined above, I aimed to prioritize variables that can be thought of as exogenous structural or institutional drivers of (or constraints over) the respective spending shares. Of course, exogeneity, in a strict sense can't always be guaranteed. The size of the military, for instance, is not just a demand-side driver of defense spending but is also a function of the allocated funds for the military. I thus aimed for a practical compromise between minimizing type 1 and type 2 errors: not omitting some of the most relevant exogenous drivers and not including too many that may cause endogeneity bias in the main estimates of interest. Of the various controls included in each model, I shall highlight the importance of three. First, I control for the size of the total government budget. Though my empirical estimation methods deal with the interdependence of budget items in other ways - see discussion below - this variable is included to explicitly estimate the impact of overall budget increases/decreases on the relative distribution of funds among key departments. Second, I include a time trend variable in all models to account for long-term secular pressures on certain budget items (eg rising healthcare costs and their impact on the health budget or the post-cold war 'peace dividend' and a shrinking defense budget in most countries as a 
result). Third, I control for the ideological leaning of the spending minister via a dummy variable taking on the value 1 when she is delegated by a left-of-centre party. For instance, if left-of-centre parties systematically favour some spending priorities (eg the social protection budget) and hence aim to place their partisan heavyweights in the corresponding ministry, the estimated impact of alignment might be confounded by the effect of ideology if this control is omitted.

Since I estimate a system of equations with potentially contemporaneously correlated errors across them, ${ }^{6}$ I follow the budget composition literature (see Breunig and Busemeyer 2012; Dreher 2008; Adolph, Breuning, and Koski, forthcoming for examples) and fit seemingly unrelated regressions (SUR) on the data (Zellner 1962). SUR has the advantage over conventional panel techniques that it increases the efficiency of the estimates when the residuals from the different equations are correlated and a different set of regressors enter as explanatory variables in the different equations. Taking into account sources of country-heterogeneity that are not explicitly modelled and therefore may introduce severe bias in the estimates in case of correlation between the country-specific errors and the regressors, I also include country fixed effects. I thus essentially model the impact of ministerial alignment on the deviation of the different spending shares from their country-specific means.

Panel-unit root tests ${ }^{7}$ with the inclusion of a linear time trend allow us to safely reject the null hypothesis that the panels have unit roots so the level specification of the model is appropriate. However, an important disadvantage of the SUR models with fixed effects is that no immediate fix for autocorrelation of the errors is available because the inclusion of lagged dependent variables causes bias in the estimates in the context of relatively short (small T panels (Nickell 1981). To get around this problem with dynamic specifications in a fixed effects framework, I also provide Prais-Winsten regressions with panel corrected standard-errors (Beck and Katz 1995) to eliminate the AR(1) process in the model residuals and render the standard error estimates of the coefficients valid.

Starting with the SUR models, the estimated system of equations can be parametrically written as follows:

$$
S_{j i t}=\alpha_{j i t 0}+\beta_{j} \beta_{j i t} * X_{j i t} \beta_{j i t}+\gamma_{j i t} * C_{j i t}+\gamma \delta_{j i}+\varepsilon_{j i t}
$$

The dependent variable $S$ stands for the spending share in budgetary category $j$, in country $i$ at time $t, \alpha_{j i t 0}$ is the regression intercept for spending category $j, X_{j i t}$ is the main independent variable (the indicator variable for PM- and FM-alignment, respectively), ${ }^{8} C_{j i t}$ is a vector of time-varying control variables that differ across the equations, $\delta \gamma_{j i}$ are country fixed effects, $\varepsilon_{j i t}$ are the residuals and $\beta_{j i t}$ and $\gamma_{j i t}$ are a set of coefficients to be estimated.

\section{Results: the impact of ministerial alignment on budget composition}

As a first test of the empirical plausibility of the theories, I provide descriptive summary statistics of budget shares under different constellations of ministerial alignment. Since the econometric tests estimate the country means by country-specific fixed effects, the spending shares shown in Figure 2 are demeaned averages, ie deviations from the country-specific means.

Though the patterns are somewhat mixed and differ greatly between the different spending shares, there are some interesting commonalities to be observed. Most 

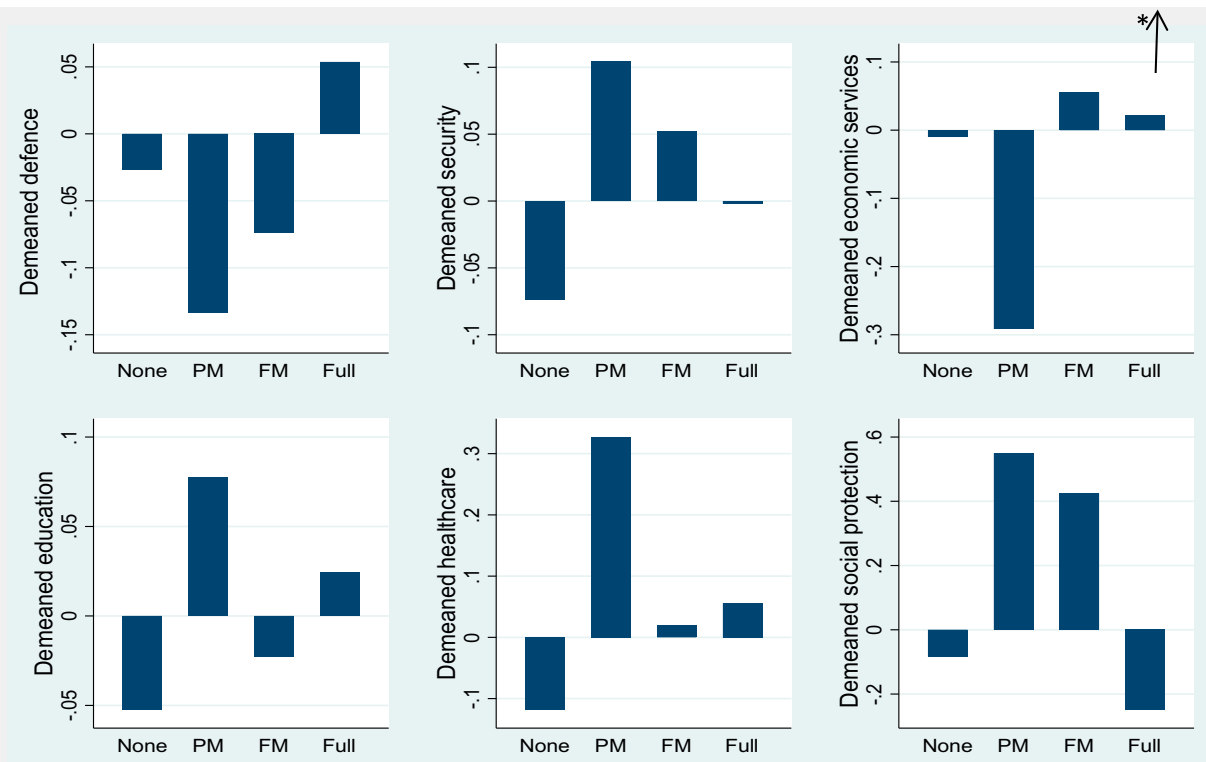

Figure 2. Demeaned spending shares under different constellations of ministerial alignment (\% of total government spending). Outsized column (1.58\%), not fully shown to preserve the axis scale.

notably, for all six spending categories, periods of non-alignment coincide with below average spending shares by the given spending ministry. The reverse seems to be true for most alignment types with important variation, however. Periods of party-alignment with the prime minister tend to go hand in hand with the above-average spending for social protection, healthcare, education and public order and safety, but below average spending for economic services and defense. Periods of finance minister alignment imply above average spending shares with the exception of education though the differences compared to the country averages are considerably smaller compared to periods of prime minister alignment. Finally, periods of full alignment (ie periods of alignment with both the prime minister and the finance minister) also tend to coincide with above average spending for most departments with the exception of social protection. Of course, these figures are simple period averages which do not take into account the effect of potential confounder variables, nor do they reveal much about the statistical significance between the group differences.

I thus proceed to estimate the econometric models. As a first step, I fit a baseline model - results shown in Table 1 - that regresses spending shares on country-fixed effects, the two lagged department-specific alignment variables and two essential controls that were highlighted above: a time trend and total budget size.

The model fits, captured by the $R^{2} \mathrm{~s}$, are very high - largely explained by the inclusion of fixed effects that soak up the within variation between countries - with the economic affairs equation being somewhat of an exception. This exception is partly due to the fact that large unmodelled one-off measures, such as bank bailouts or recapitalization of public enterprises, fall in this category. The Breusch-Pagan $x^{2}$ test for residual independence allows for an easy rejection of the independent errors null-hypothesis, providing a 
Table 1. Coefficient estimates from the baseline SUR model.

\begin{tabular}{lcccccc}
\hline & Defence & Security & Econ & Educ & Health & Social \\
\hline L.Pm-alignment & 0.143 & 0.099 & -0.375 & 0.101 & 0.178 & 0.572 \\
& $(2.12)^{* *}$ & $(1.96)^{*}$ & $(1.82)^{*}$ & $(1.28)$ & $(1.74)^{*}$ & $(3.39)^{* * *}$ \\
L.Fm-alignment & 0.003 & -0.001 & 0.333 & -0.114 & 0.187 & -0.183 \\
& $(0.04)$ & $(0.02)$ & $(1.65)^{*}$ & $(1.47)$ & $(1.82)^{*}$ & $(1.07)$ \\
Total expenditure & 0.017 & 0.339 & 0.883 & 0.110 & 0.473 & -1.533 \\
& $(0.07)$ & $(1.93)^{*}$ & $(1.01)$ & $(0.35)$ & $(1.20)$ & $(2.12)^{* *}$ \\
Trend & -0.063 & -0.002 & -0.045 & -0.011 & 0.137 & 0.190 \\
& $(14.40)^{* * *}$ & $(0.67)$ & $(2.73)^{* * *}$ & $(1.91)^{*}$ & $(18.41)^{* * *}$ & $(14.01)^{* * *}$ \\
Constant & 5.099 & 4.534 & 12.210 & 14.810 & 15.146 & 24.986 \\
& $(27.89)^{* * *}$ & $(31.52)^{* * *}$ & $(17.79)^{* * *}$ & $(60.79)^{* * *}$ & $(48.52)^{* * *}$ & $(43.62)^{* * *}$ \\
Fixed effects & YES & YES & YES & YES & YES & YES \\
$R^{2}$ & 0.95 & 0.87 & 0.56 & 0.89 & 0.88 & 0.87 \\
$N$ & 674 & 674 & 674 & 674 & 674 & 674 \\
RMSE & 0.63 & 0.47 & 2.37 & 0.84 & 1.07 & 1.95 \\
Breusch-Pagan $x^{2}$ & & \multicolumn{2}{c}{$539.193^{* * *}$} & & & \\
\hline
\end{tabular}

${ }^{*} p<0.1 ;{ }^{* *} p<0.05 ;{ }^{* * *} p<0.01$.

strong justification for the choice of SUR estimation. Indeed, the cross-equation correlation matrix (see Table A6 in the Appendix) reveals some interesting patterns, such as the large negative correlation coefficient $(-0.46)$ between the social protection and economic affairs equations, suggesting that the two spending shares respond to shocks in the opposite direction: when the share of social spending rises, spending on economic affairs tends to drop. By contrast, increases in the health and the education budget tend to go hand in hand with a positive correlation coefficient between the error terms (0.45) (Table 2).

The main coefficients of interest are the two alignment dummies. Of the six spending categories, four provide evidence for the positive impact of ministerial alignment, although the level of significance varies between the budget items (strongly significant for social protection and defense and only weakly for public order and safety and healthcare). For the remaining two other spending areas, the coefficient is either positive and non-significant (education) or go directly against the prime minister alignment hypothesis with a negative significant coefficient (economic services). As for the alignment with the finance minister, the patterns based on the baseline model are considerably weaker: only the economic budget and the healthcare budget show a positive association with ministerial alignment and the coefficients are significant only at the $10 \%$ level.

These initial patterns, however, need to be treated with caution as they do not take into account some of the structural, institutional and political drivers of spending composition. I thus proceed to estimate the same models with an extended set of controls that include variables that enter all models (GDP growth, GDP per capita, public debt stock, annual change in the structural fiscal balance, trade penetration, Gallagher index of disproportionality (Gallagher 1991) of electoral systems, coalition size and a dummy for leftwing ministers heading spending departments as well as for years when a general election is held) as well as variables that relate to only one or two of the spending categories (size of armed forces for defense, riots and urban population for public order and safety, the size of the urban population for economic services, the youth dependency ratio for education, the old dependency ratio and life expectancy for healthcare and the old dependency ratio and the level of unemployment for social protection). Table A3 in the Appendix details the measurement and the source of all the control variables included the specifications. 
Table 2. Coefficient estimates from the extended SUR models.

\begin{tabular}{|c|c|c|c|c|c|c|}
\hline & Defence & Security & Econ & Educ & Health & Social \\
\hline PM-alignment & $\begin{array}{c}0.134 \\
(2.00)^{* *}\end{array}$ & $\begin{array}{l}0.046 \\
(0.97)\end{array}$ & $\begin{array}{c}-0.605 \\
(2.99)^{* * *}\end{array}$ & $\begin{array}{c}-0.033 \\
(0.44)\end{array}$ & $\begin{array}{c}0.202 \\
(2.09)^{* *}\end{array}$ & $\begin{array}{c}0.512 \\
(3.34)^{* * * *}\end{array}$ \\
\hline FM-alignment & $\begin{array}{c}-0.020 \\
(0.33)\end{array}$ & $\begin{array}{c}-0.010 \\
(0.24)\end{array}$ & $\begin{array}{c}0.593 \\
(3.03)^{* * *}\end{array}$ & $\begin{array}{c}-0.119 \\
(1.60)\end{array}$ & $\begin{array}{l}0.158 \\
(1.62)\end{array}$ & $\begin{array}{c}-0.157 \\
(1.02)\end{array}$ \\
\hline Total expenditure & $\begin{array}{l}0.577 \\
(1.33)\end{array}$ & $\begin{array}{l}0.399 \\
(1.28)\end{array}$ & $\begin{array}{c}3.682 \\
(2.14)^{* *}\end{array}$ & $\begin{array}{c}1.415 \\
(2.54)^{* *}\end{array}$ & $\begin{array}{c}2.149 \\
(3.11)^{* * *}\end{array}$ & $\begin{array}{c}-4.099 \\
(3.28)^{* * *}\end{array}$ \\
\hline Trend & $\begin{array}{c}-0.051 \\
(4.31)^{* * *}\end{array}$ & $\begin{array}{c}0.020 \\
(2.56)^{* *}\end{array}$ & $\begin{array}{c}-0.012 \\
(0.29)\end{array}$ & $\begin{array}{c}-0.020 \\
(1.36)\end{array}$ & $\begin{array}{c}0.107 \\
(3.75)^{* * *}\end{array}$ & $\begin{array}{c}0.300 \\
(7.66)^{* * * *}\end{array}$ \\
\hline L.Left minister & $\begin{array}{l}0.078 \\
(1.42)\end{array}$ & $\begin{array}{c}-0.015 \\
(0.38)\end{array}$ & $\begin{array}{l}0.076 \\
(0.44)\end{array}$ & $\begin{array}{c}0.149 \\
(2.41)^{* *}\end{array}$ & $\begin{array}{c}-0.259 \\
(3.07)^{* * *}\end{array}$ & $\begin{array}{c}-0.412 \\
(3.17)^{* * *}\end{array}$ \\
\hline GDP per capita & $\begin{array}{l}0.000 \\
(0.02)\end{array}$ & $\begin{array}{c}-0.017 \\
(3.09)^{* * *}\end{array}$ & $\begin{array}{l}-0.051 \\
(1.75)^{*}\end{array}$ & $\begin{array}{c}-0.006 \\
(0.69)\end{array}$ & $\begin{array}{l}0.020 \\
(1.60)\end{array}$ & $\begin{array}{l}-0.044 \\
(1.98)^{* *}\end{array}$ \\
\hline Growth & $\begin{array}{l}0.003 \\
(0.32)\end{array}$ & $\begin{array}{c}0.034 \\
(5.99)^{* * *}\end{array}$ & $\begin{array}{l}-0.068 \\
(2.14)^{* *}\end{array}$ & $\begin{array}{c}0.022 \\
(2.25)^{* *}\end{array}$ & $\begin{array}{l}0.016 \\
(1.28)\end{array}$ & $\begin{array}{l}-0.045 \\
(1.94)^{*}\end{array}$ \\
\hline Trade & $\begin{array}{c}0.003 \\
(1.83)^{*}\end{array}$ & $\begin{array}{c}-0.002 \\
(1.18)\end{array}$ & $\begin{array}{l}0.005 \\
(0.66)\end{array}$ & $\begin{array}{c}0.006 \\
(2.50)^{* *}\end{array}$ & $\begin{array}{l}0.001 \\
(0.46)\end{array}$ & $\begin{array}{l}-0.013 \\
(2.48)^{* *}\end{array}$ \\
\hline Debt & $\begin{array}{c}-0.002 \\
(1.21)\end{array}$ & $\begin{array}{c}-0.010 \\
(7.61)^{* * *}\end{array}$ & $\begin{array}{c}-0.008 \\
(1.05)\end{array}$ & $\begin{array}{c}-0.024 \\
(10.32)^{* * *}\end{array}$ & $\begin{array}{c}-0.037 \\
(12.70)^{* * *}\end{array}$ & $\begin{array}{c}-0.004 \\
(0.66)\end{array}$ \\
\hline$\Delta$ Balance & $\begin{array}{c}-0.040 \\
(2.68)^{* * * *}\end{array}$ & $\begin{array}{l}0.006 \\
(0.58)\end{array}$ & $\begin{array}{l}-0.115 \\
(1.93)^{*}\end{array}$ & $\begin{array}{l}0.024 \\
(1.27)\end{array}$ & $\begin{array}{c}0.054 \\
(2.29)^{* *}\end{array}$ & $\begin{array}{c}0.128 \\
(2.98)^{* * * *}\end{array}$ \\
\hline Disproportionality & $\begin{array}{l}0.000 \\
(0.01)\end{array}$ & $\begin{array}{l}-0.017 \\
(1.80)^{*}\end{array}$ & $\begin{array}{l}-0.107 \\
(2.12)^{* *}\end{array}$ & $\begin{array}{l}0.010 \\
(0.66)\end{array}$ & $\begin{array}{c}0.041 \\
(2.04)^{* *}\end{array}$ & $\begin{array}{c}0.063 \\
(1.72)^{*}\end{array}$ \\
\hline Coalitionsize & $\begin{array}{l}-0.056 \\
(2.12)^{* *}\end{array}$ & $\begin{array}{c}-0.005 \\
(0.26)\end{array}$ & $\begin{array}{l}0.155 \\
(1.49)\end{array}$ & $\begin{array}{c}-0.036 \\
(1.12)\end{array}$ & $\begin{array}{c}-0.053 \\
(1.28)\end{array}$ & $\begin{array}{l}-0.124 \\
(1.65)^{*}\end{array}$ \\
\hline Election & $\begin{array}{c}-0.034 \\
(0.64)\end{array}$ & $\begin{array}{l}0.003 \\
(0.07)\end{array}$ & $\begin{array}{c}-0.040 \\
(0.19)\end{array}$ & $\begin{array}{l}0.039 \\
(0.59)\end{array}$ & $\begin{array}{c}-0.019 \\
(0.23)\end{array}$ & $\begin{array}{l}0.124 \\
(0.82)\end{array}$ \\
\hline Armed forces & $\begin{array}{c}0.588 \\
(6.51)^{* * *}\end{array}$ & & & & & \\
\hline Urban pop. & & $\begin{array}{c}0.096 \\
(8.18)^{* * *}\end{array}$ & $\begin{array}{l}0.063 \\
(1.30)\end{array}$ & & & \\
\hline Riot & & $\begin{array}{c}-0.007 \\
(0.14)\end{array}$ & & & & \\
\hline Dependency: young & & & & $\begin{array}{c}-0.080 \\
(4.43)^{* * *}\end{array}$ & & \\
\hline Dependency: old & & & & & $\begin{array}{c}0.059 \\
(1.83)^{*}\end{array}$ & $\begin{array}{l}-0.102 \\
(1.88)^{*}\end{array}$ \\
\hline Life expectancy & & & & & $\begin{array}{l}0.029 \\
(0.37)\end{array}$ & \\
\hline Unemployment & & & & & & $\begin{array}{c}0.277 \\
(10.74)^{* * *}\end{array}$ \\
\hline Constant & $\begin{array}{c}4.392 \\
(16.48)^{* * *}\end{array}$ & $\begin{array}{c}-2.992 \\
(3.14)^{* * *}\end{array}$ & $\begin{array}{c}7.878 \\
(1.96)^{* *}\end{array}$ & $\begin{array}{c}17.385 \\
(27.43)^{* * * *}\end{array}$ & $\begin{array}{l}11.466 \\
(1.92)^{*}\end{array}$ & $\begin{array}{c}26.636 \\
(22.90)^{* * *}\end{array}$ \\
\hline Fixed effects & Yes & Yes & Yes & Yes & Yes & Yes \\
\hline$R^{2}$ & 0.95 & 0.90 & 0.57 & 0.91 & 0.91 & 0.91 \\
\hline$N$ & 662 & 662 & 662 & 662 & 662 & 662 \\
\hline RMSE & 0.59 & 0.42 & 2.34 & 0.73 & 0.92 & 1.68 \\
\hline Breusch-Pagan $x^{2}$ & \multicolumn{6}{|c|}{$502.359^{* * *}$} \\
\hline
\end{tabular}

${ }^{*} p<0.1$; ${ }^{* *} p<0.05$; ${ }^{* * *} p<0.01$.

In these extended models, the $R^{2} \mathrm{~s}$ further edge up, especially for the health and the social protection budget while the Bresuch-Pagan $X 2$ statistic continues to provide strong evidence for cross-equation correlation of the errors. Of the four budget items where prime minister alignment had a significant positive impact in the baseline models, three survive the inclusion of the long set of controls: defense, healthcare and social protection, all strongly significant $(p<0.05)$. By contrast, the public order and safety budget and the education budget now appear unrelated to prime minister alignment whereas the economic budget is significantly lower in these alignment years, 
contrary to my hypothesis. As for finance minister alignment, five of the six coefficients are non-significant and the only exception is the economic budget that is significantly larger in times of ministerial alignment with the finance minister.

The substantive sizes of these estimates are broadly comparable when taking into account the different average sizes of the spending categories. For instance, the point estimate of 0.51 for the impact of ministerial alignment with the prime minister on the social protection budget is similar to the estimate of 0.2 on the health budget in relative terms. While the former takes up around the third of total spending on average, the latter's average share is only $13 \%$. This implies that switching from a scenario of non-alignment to one of alignment amounts to around $2 \%$ higher spending share for the respective domains expressed in terms of their sample average. Using the same metric, the point estimate of 0.13 for the defense budget under prime minister alignment and the 0.59 for the economic budget under finance minister alignment amount to considerably larger relative impacts. For the former, the estimate is $3.7 \%$ of the sample average of the defense budget while the former it is $5.2 \%$ of the average economic budget.

In addition to the alignment dummies, most of the control variables are also significant predictors of at least some of the budget categories. While a detailed discussion of their impact lies beyond the scope of this paper, for each spending category I shall highlight some of the most important predictors. The defense budget appears to be one of the main victims of periods of fiscal adjustment as its relative share responds negatively to improvements in the structural budget balance. Moreover, in line with the idea of the 'peace dividend' in the post-cold war era, it also gets smaller over time on average. Defense spending also diminishes relative to other items when more parties are in government, implying that it is not a favourite target of coalition partners tapping into the common pool. As for spending on public order and safety, its relative share is increasing over time, it tends to be lower in relatively poor countries but increases with growth. Somewhat surprisingly, the economic budget is negatively associated with higher growth rates and similar to the defense budget, is one of the main victims of fiscal adjustment. It also tends to be smaller in less proportionate electoral systems. The education budget tends to be cut under periods of fiscal pressure (when the public debt stock is high) and it responds positively to higher growth rates and trade penetration. Finally, the healthcare and the social protection budget tend to be shielded from cuts as their share increase in periods of fiscal adjustment. While the health budget tends to be larger under less proportionate electoral systems, the relative share of spending on social protection diminishes when growth is higher and countries are wealthier measured by GDP per capita. Spending on social protection also tends to fall under higher trade penetration, contrary to the compensation hypothesis prominent in the political economy literature (eg Rodrik 1998).

Beyond these significant estimates, it is also noteworthy that some of the key controls do not significantly predict budget composition. For instance, the partisanship of the spending minister is associated with the spending share of only two of the six budget items and for two of these three - healthcare and social protection - in an unexpected direction: left-wing spending ministers are associated with lower budget shares. Only the education portfolio is associated with higher relative funding under left-wing ministers. Moreover, election years are not significantly associated with higher or lower 
spending shares for any of the six categories, suggesting that political budget cycles, to the extent they occur, are broadly spread out between different spending items on average.

\section{Robustness and extensions}

While the SUR specification is often employed by the budget composition literature to enhance estimation efficiency, it is vulnerable to imprecisely estimated standard errors when the residuals are auto-correlated. As a first robustness check, I thus estimate Prais-Winsten regressions and panel-corrected standard errors to correct for first-order serial correlation between the error terms as well as contemporaneous correlation across panels due to unmodelled common shocks. ${ }^{9}$ The estimates with panel corrected standard errors are shown in Table 3.

The results are similar to the SUR estimation with defense, healthcare and social protection spending being positively associated with prime minister alignment. Additionally and in contrast to the fully specified SUR models, now spending on public order and safety is also significantly higher under prime minister alignment while the lower share of economic spending under prime minister alignment loses significance (while the impact of finance minister alignment is still positive and borderline significant $(p=0.055)$ for economic spending).

Secondly, I consider the potential problem arising from bounded nature of the dependent variable, potentially yielding predicted values outside the 0-1 bound and biased coefficients when estimating it in a linear form (Adolph, Breuning, and Koski, forthcoming, 13). I thus return to the SUR models but express the dependent variable in terms of proportion rather than percentages and log-transform it via

$$
S_{j}^{*}=\frac{S_{j}}{1-S_{j}}
$$

where $S_{j}^{*}$ is the log-transformed dependent variable for spending category $j$, and $S_{j}$ is the original dependent variable expressed as a proportion, bounded between 0 and 1 . The results - shown in Table A4 in the Appendix - are quasi-identical to the results obtained under linear SUR estimation. Three of the six budget items - defense, healthcare and social protection - increase under party-alignment with the prime minister, while the economic budget decreases under prime minister alignment and increases in periods of financeminister alignment. Also in line with the results from the linear models, using the fully specified models including the long list of controls, spending on public order and safety as well as the education budget appear unrelated to the ministerial alignment patterns.

Lastly, I consider the possibility that the alignment patterns I have uncovered are mediated by partisanship. While the fully specified models I have presented included a left-wing ideology dummy for spending ministers delegated by left-of-centre parties as a control, it is conceivable that alignment patterns play out differently on the two ends of the ideological spectrum (for instance, left-wing prime ministers may favour the spending priorities of their co-partisan colleagues, whereas right-wing prime ministers rely on them for spending restraint). If this is the case, one should observe significant interaction effects between the alignment variables and the left-wing minister dummy used before. The last set of models thus re-estimate the system of equations via SUR with this 
Table 3. Coefficient estimates from Prais-Winsten regression and PCSE.

\begin{tabular}{|c|c|c|c|c|c|c|}
\hline & Defence & Security & Econ & Educ & Health & Defence \\
\hline L.PM-alignment & $\begin{array}{c}0.125 \\
(3.68)^{* * * *}\end{array}$ & $\begin{array}{c}0.092 \\
(2.28)^{* *}\end{array}$ & $\begin{array}{c}-0.408 \\
(1.01)\end{array}$ & $\begin{array}{l}0.034 \\
(0.44)\end{array}$ & $\begin{array}{c}0.170 \\
(2.01)^{* *}\end{array}$ & $\begin{array}{c}0.543 \\
(2.47)^{* *}\end{array}$ \\
\hline L.FM-alignment & $\begin{array}{c}-0.055 \\
(1.58)\end{array}$ & $\begin{array}{c}-0.089 \\
(2.60)^{* * * *}\end{array}$ & $\begin{array}{c}0.563 \\
(1.74)^{*}\end{array}$ & $\begin{array}{c}-0.085 \\
(1.04)\end{array}$ & $\begin{array}{c}-0.001 \\
(0.01)\end{array}$ & $\begin{array}{c}-0.308 \\
(1.58)\end{array}$ \\
\hline Total expenditure & $\begin{array}{l}0.604 \\
(1.63)\end{array}$ & $\begin{array}{c}0.614 \\
(1.81)^{*}\end{array}$ & $\begin{array}{l}6.763 \\
(1.61)\end{array}$ & $\begin{array}{l}0.349 \\
(0.48)\end{array}$ & $\begin{array}{c}-0.263 \\
(0.39)\end{array}$ & $\begin{array}{l}-8.083 \\
(5.10)^{* * * *}\end{array}$ \\
\hline Trend & $\begin{array}{c}-0.058 \\
(5.01)^{* * *}\end{array}$ & $\begin{array}{c}0.019 \\
(2.45)^{* *}\end{array}$ & $\begin{array}{c}-0.111 \\
(1.19)\end{array}$ & $\begin{array}{c}-0.025 \\
(1.27)\end{array}$ & $\begin{array}{c}0.201 \\
(6.01)^{* * * *}\end{array}$ & $\begin{array}{c}0.267 \\
(6.05)^{* * * *}\end{array}$ \\
\hline L.Left minister & $\begin{array}{c}0.144 \\
(3.49)^{* * *}\end{array}$ & $\begin{array}{l}0.031 \\
(1.04)\end{array}$ & $\begin{array}{l}0.105 \\
(0.30)\end{array}$ & $\begin{array}{l}0.068 \\
(1.15)\end{array}$ & $\begin{array}{c}-0.056 \\
(0.80)\end{array}$ & $\begin{array}{l}-0.279 \\
(1.75)^{*}\end{array}$ \\
\hline GDP per capita & $\begin{array}{c}-0.004 \\
(0.80)\end{array}$ & $\begin{array}{c}-0.021 \\
(4.10)^{* * *}\end{array}$ & $\begin{array}{c}-0.062 \\
(1.22)\end{array}$ & $\begin{array}{l}0.008 \\
(0.72)\end{array}$ & $\begin{array}{l}0.006 \\
(0.40)\end{array}$ & $\begin{array}{c}-0.001 \\
(0.03)\end{array}$ \\
\hline Growth & $\begin{array}{c}-0.002 \\
(0.30)\end{array}$ & $\begin{array}{c}0.019 \\
(3.81)^{* * *}\end{array}$ & $\begin{array}{c}-0.020 \\
(0.52)\end{array}$ & $\begin{array}{l}0.006 \\
(0.95)\end{array}$ & $\begin{array}{l}0.010 \\
(0.91)\end{array}$ & $\begin{array}{c}-0.056 \\
(2.98)^{* * * *}\end{array}$ \\
\hline Trade & $\begin{array}{c}0.004 \\
(2.46)^{* *}\end{array}$ & $\begin{array}{l}0.000 \\
(0.31)\end{array}$ & $\begin{array}{l}0.011 \\
(0.83)\end{array}$ & $\begin{array}{c}-0.000 \\
(0.14)\end{array}$ & $\begin{array}{c}-0.001 \\
(0.27)\end{array}$ & $\begin{array}{l}-0.020 \\
(3.07)^{* * * *}\end{array}$ \\
\hline Debt & $\begin{array}{l}-0.004 \\
(2.54)^{* * *}\end{array}$ & $\begin{array}{c}-0.012 \\
(13.01)^{* * *}\end{array}$ & $\begin{array}{l}0.005 \\
(0.33)\end{array}$ & $\begin{array}{c}-0.023 \\
(7.08)^{* * *}\end{array}$ & $\begin{array}{l}-0.032 \\
(9.31)^{* * * *}\end{array}$ & $\begin{array}{c}-0.007 \\
(0.61)\end{array}$ \\
\hline$\Delta$ Balance & $\begin{array}{l}-0.016 \\
(1.85)^{*}\end{array}$ & $\begin{array}{c}0.017 \\
(2.67)^{* * *}\end{array}$ & $\begin{array}{c}-0.105 \\
(1.29)\end{array}$ & $\begin{array}{c}0.031 \\
(2.92)^{* * *}\end{array}$ & $\begin{array}{c}0.051 \\
(3.61)^{* * * *}\end{array}$ & $\begin{array}{c}0.115 \\
(3.61)^{* * *}\end{array}$ \\
\hline Proportionality & $\begin{array}{c}-0.004 \\
(0.49)\end{array}$ & $\begin{array}{l}-0.014 \\
(2.64)^{* * *}\end{array}$ & $\begin{array}{c}-0.042 \\
(0.65)\end{array}$ & $\begin{array}{c}-0.002 \\
(0.12)\end{array}$ & $\begin{array}{l}0.018 \\
(1.12)\end{array}$ & $\begin{array}{l}0.033 \\
(0.69)\end{array}$ \\
\hline Election & $\begin{array}{l}-0.043 \\
(2.32)^{* *}\end{array}$ & $\begin{array}{l}0.015 \\
(0.78)\end{array}$ & $\begin{array}{l}0.012 \\
(0.07)\end{array}$ & $\begin{array}{l}0.026 \\
(0.77)\end{array}$ & $\begin{array}{c}-0.029 \\
(0.76)\end{array}$ & $\begin{array}{l}0.027 \\
(0.26)\end{array}$ \\
\hline Coalitionsize & $\begin{array}{c}-0.013 \\
(0.93)\end{array}$ & $\begin{array}{c}-0.020 \\
(1.54)\end{array}$ & $\begin{array}{c}0.246 \\
(2.24)^{* *}\end{array}$ & $\begin{array}{l}-0.060 \\
(2.45)^{* *}\end{array}$ & $\begin{array}{l}-0.067 \\
(2.58)^{* * * *}\end{array}$ & $\begin{array}{l}-0.258 \\
(5.08)^{* * *}\end{array}$ \\
\hline Armedforces & $\begin{array}{c}0.456 \\
(7.17)^{* * * *}\end{array}$ & & & & & \\
\hline Urban pop. & & $\begin{array}{c}0.086 \\
(8.32)^{* * * *}\end{array}$ & $\begin{array}{c}0.165 \\
(2.21)^{* *}\end{array}$ & & & \\
\hline Riot & & $\begin{array}{l}0.007 \\
(0.20)\end{array}$ & & & & \\
\hline Dependency: young & & & & $\begin{array}{c}-0.103 \\
(3.22)^{* * *}\end{array}$ & & \\
\hline Dependency: old & & & & & $\begin{array}{c}0.058 \\
(1.88)^{*}\end{array}$ & $\begin{array}{l}0.090 \\
(1.13)\end{array}$ \\
\hline Life expectancy & & & & & $\begin{array}{l}-0.177 \\
(2.67)^{* * * *}\end{array}$ & \\
\hline Unemployment & & & & & & $\begin{array}{c}0.234 \\
(6.73)^{* * *}\end{array}$ \\
\hline Constant & $\begin{array}{c}4.741 \\
(16.17)^{* * * *}\end{array}$ & $\frac{-2.048}{(2.41)^{* *}}$ & $\begin{array}{c}-1.998 \\
(0.32)\end{array}$ & $\begin{array}{c}18.428 \\
(16.29)^{* * *}\end{array}$ & $\begin{array}{c}28.307 \\
(5.37)^{* * * *}\end{array}$ & $\begin{array}{c}24.765 \\
(19.46)^{* * *}\end{array}$ \\
\hline Fixed effects & Yes & Yes & Yes & Yes & Yes & Yes \\
\hline$R^{2}$ & 0.93 & 0.96 & 0.79 & 0.99 & 0.98 & 0.98 \\
\hline$N$ & 662 & 662 & 662 & 662 & 662 & 662 \\
\hline RMSE & 0.46 & 0.31 & 2.18 & 0.57 & 0.67 & 1.30 \\
\hline Pasaran test statistic & $-1.97^{* *}$ & $5.71 * * *$ & $2.99 * * *$ & $5.314^{* * *}$ & $5.891^{* * * *}$ & 1.327 \\
\hline
\end{tabular}

${ }^{*} p<0.1 ;{ }^{* *} p<0.05 ;{ }^{* * *} p<0.01$.

interaction explicitly modelled for each spending category. As Table A5 shows in the Appendix, in five of the six such spending categories, no such interaction dynamics are found and the only significant interaction term concerns the social protection budget where co-partisanship with the finance minister on the left-end of the ideological spectrum is associated with lower rather than higher spending share for social protection. Overall, therefore, most of the alignment patterns uncovered before are largely ideology-blind to the extent that the partisan leaning of the spending minister under question does not moderate or amplify the impact of co-partisanship. 


\section{Discussion and conclusion}

In the labyrinth of spending shares and different constellations of ministerial alignments, it is inherently difficult to disentangle a neat story that is consistent across countries, time and types of budgetary items. The aim that was set out in the beginning of this article is to find some commonalities in the underlying intra-governmental logic that drives public spending composition. By restricting the analysis to within-country changes and controlling for a multitude of exogenous forces that impact on public spending composition, I offered two hypotheses on such logic: one derived from the portfolio allocation approach in the coalition formation literature emphasizing the role of formateur parties and therefore the prime minister, the other inspired by the common pool resource approach in public budgeting placing the finance minister in the centre-stage. The overall weight of evidence, as summarized in Table 4, provides more support for the first perspective: alignment with the prime minister's party is a considerably stronger predictor of budget outcomes compared to alignment with the finance minister's party. The relative share of three of the six spending categories - including the two largest items, social protection and healthcare - unambiguously increase under prime minister alignment, while the evidence for public order and safety is less robust. By contrast, only the economic budget appears to benefit from finance minister alignment.

The substantive size of some of the estimated effects is also non-trivial. Beyond coalition bargaining's relevance for the partisan objectives of political parties, its outcome also has long-term consequences for the resolution of conflicting electoral demands by social groups and other national priorities. Take the example of spending on social protection which shows the substantively largest and statistically most robust correspondence between prime minister alignment and spending shares. Whether the social (or welfare) portfolio is occupied by one of the prime minister's co-partisan cabinet colleagues or by a coalition partner/non-partisan minister implies half a percentage point difference for the budget share for social protection, when expressed in terms of total spending (see Table 4). When projecting this onto a longer time period, this amounts to a permanent cut (or expansion) of particular social programs with the potential to introduce new conflict lines in the electoral arena. Likewise, the estimated 0.13 percentage point difference in the share of defense spending between different alignment patterns may make a crucial difference for weather NATO members, for instance, may move towards or away from their committed spending target of $2 \%$ of GDP.

A few limitations of these findings, however, merit further analysis. One concerns the specific causal mechanism that connects ministerial alignment with budget outcomes. In the simplest formulation of the portfolio allocation approach, coalition partners arrive to the negotiation table with fixed preferences on portfolio salience and spending priorities and bargain for portfolio positions that maximize their potential to act upon those

Table 4. Summary of coefficient estimates (expressed in \% of total spending).

\begin{tabular}{|c|c|c|c|c|c|c|c|}
\hline & & Defence & $\begin{array}{l}\text { Public order } \\
\text { and safety }\end{array}$ & Economic & Education & Healthcare & $\begin{array}{c}\text { Social } \\
\text { Protection }\end{array}$ \\
\hline \multirow[t]{2}{*}{ PM-alignment } & SUR & $0.13^{* *}$ & 0.05 & $-0.61^{* * *}$ & -0.03 & $0.2^{* *}$ & $0.51 * *$ \\
\hline & Prais-Winsten & $0.13 * * *$ & $0.09 * *$ & -0.41 & 0.03 & $0.17 * *$ & $0.54^{* *}$ \\
\hline \multirow[t]{2}{*}{ FM-alignment } & SUR & -0.02 & -0.01 & $0.59 * * *$ & -0.12 & 0.16 & -0.16 \\
\hline & Prais-Winsten & -0.06 & $-0.09 * * *$ & $0.56^{*}$ & -0.09 & 0 & -0.31 \\
\hline
\end{tabular}


preferences. The empirical findings, however, leave open an important question in the underlying causal mechanism: do the spending outcomes merely reflect these underlying preferences, or in other words, do higher/lower spending shares under ministerial alignment/non-alignment simply suggest that formateur parties succeeded/failed to succeed in obtaining ministerial portfolios that they wanted to flood with resources in the first place? Or alternatively, are spending share differentials testimony to ministerial autonomy in the strict sense of the word, whereby appointed ministers are more successful in ensuring higher funding for their departments when their co-partisans occupy one or both of the two most important budgetary positions? Though the empirical patterns shown by this article are important in their own right, one needs to understand them with a certain dose of agnosticism with regards to the specifying underlying causal mechanism.

The second limitation of the findings concerns the different estimated effects across budgetary items as well as across different alignment patterns. While for the two largest budgetary items, healthcare and social protection, as well as for the defense budget the evidence provided is unambiguous, for spending on public order and safety it was contingent on estimation method, and for economic services, the two alignment types point to opposite directions. Finally, education spending appears unrelated to the partisan alignment of the education minister. Whether these differences arise from the different institutional characteristics, political salience or functional pressures underpinning these budgetary items lies beyond the purview of this article.

Finally, the impact of prime minister alignment was shown to be considerably stronger than the influence of finance minister alignment, raising further questions yet to be answered: is it prime ministers' position of 'first among equals' that trumps the procedural powers of the finance minister and sways budget allocations in her party's favour or they tend to have stronger partisan preferences to begin with? Again, at this point, no definitive answer can be provided to this question. Overall, however, the agency-centred exploratory analysis I offered is nevertheless an important contribution to the budget allocation literature that future studies can build upon with the above questions in mind.

\section{Notes}

1. The two exceptions are Finland and Switzerland where data are available from 1990 onwards.

2. The Classification of Functions of Government developed by the United Nations (United Nations Statistics Division 1999) classifies government spending into 10 functional categories: general public services, defense, public law and order, economic affairs, environmental protection, housing, health, recreation and culture, education, and social protection.

3. For an extensive review of the common pool approach, see also Raudla (2010).

4. In cases of no explicit references to the national economy in the ministry's name, I used the heads of the ministry for industry, business or transport to identify the relevant minister.

5. The database is available at http://www.kolumbus.fi/taglarsson/dokumentit/governm2.htm.

6. In fact, since the spending shares are expressed as a \% of the total budget, any omitted variable that shows up in the error term in one equation - for instance, shocks affecting only one of the spending items - is likely to be negatively correlated with the error term in another equation.

7. I employ the Im-Pesaran-Shin test due to the slight imbalance in the panel structure of the data. For all six spending categories, the test allows us to reject the $\mathrm{H}_{0}$ of unit root in all panels at the 0.001 level. 
8. To take into account the delays and multiple stages in the budget process (Hallerberg 2009; Adolph, Breuning, and Koski, forthcoming) I introduce the alignment dummies as first lags in each model.

9. Tests for the serial correlation of the residuals reject the $\mathrm{H}_{0}$ of non-correlated errors at the 0.001 level for all six spending categories. Likewise, Pesaran tests indicate cross-sectional dependence between the error terms, underscoring the need for standard error correction via pcse.

\section{Disclosure statement}

No potential conflict of interest was reported by the author.

\section{Funding}

This work was supported by H2020 European Research Council [grant number 338875].

\section{References}

Adolph, C., C. Breuning, and C. Koski. Forthcoming. "The Political Economy of Budget Trade-Offs." Journal of Public Policy.

Adsera, A., and C. Boix. 2002. "Trade, Democracy, and the Size of the Public Sector: The Political Underpinnings of Openness." International Organization 56 (2): 229-262.

Agthe, D. E., R. B. Billings, and J. R. Marchand. 1996. "Socioeconomic and Political Determinants of State Spending on Environmental Programs." The American Economist 40 (1): 24-30.

Alesina, A., and R. Perotti. 1999. "Budget Deficits and Budget Institutions." In Fiscal Institutions and Fiscal Performance, edited by J. M. Poterba and J. von Hagen, 13-36. Chicago: Chicago \& London: University of Chicago Press.

Alexiadou, D. 2015. "Ideologues, Partisans, and Loyalists: Cabinet Ministers and Social Welfare Reform in Parliamentary Democracies." Comparative Political Studies 48 (8): 1051-1086.

Back, H., M. Debus, and P. Dumont. 2011. "Who Gets What in Coalition Governments? Predictors of Portfolio Allocation in Parliamentary Democracies." European Journal of Political Research 50 (4): 441-478.

Back, H., W. C. Muller, and B. Nyblade. 2017. "Multiparty Government and Economic Policy-Making." Public Choice 170: 33-62.

Bawn, K., and F. Rosenbluth. 2006. "Short Versus Long Coalitions Electoral Accountability and the Size of the Public Sector." American Journal of Political Science 50 (2): 251-265.

Beck, N., and J. N. Katz. 1995. "What to Do (and Not to Do) with Time-Series Cross-Section Data." American Political Science Review 89 (3): 634-647.

Bertoa, C. F. 2019. Database on Who Governs in Europe and Beyond, PSGo. Available at: whogoverns.eu.

Brauninger, T. 2005. "A Partisan Model of Government Expenditure." Public Choice 125 (3-4): 409429.

Brender, A., and A. Drazen. 2013. "Elections, Leaders, and the Composition of Government Spending." Journal of Public Economics 97: 18-31.

Breunig, C. 2011. "Reduction, Stasis, and Expansion of Budgets in Advanced Democracies." Comparative Political Studies 44 (8): 1060-1088.

Breunig, C., and M. R. Busemeyer. 2012. "Fiscal Austerity and the Trade-off Between Public Investment and Social Spending." Journal of European Public Policy 19 (6): 921-938.

Browne, E. C., and M. N. Franklin. 1973. "Aspects of Coalition Payoffs in European Parliamentary Democracies." American Political Science Review 67 (2): 453-469.

Carroll, R., and G. W. Cox. 2012. "Shadowing Ministers: Monitoring Partners in Coalition Governments." Comparative Political Studies 45 (2): 220-236. 
Castro, V. 2017. "The Impact of Fiscal Consolidations on the Functional Components of Government Expenditures." Economic Modelling 60: 138-150.

Dreher, A., et al. 2008. "The Impact of Globalization on the Composition of Government Expenditures: Evidence From Panel Data." Public Choice 134 (3-4): 263-292.

Dunleavy, P., and S. Bastow. 2001. "Modelling Coalitions that Cannot Coalesce: A Critique of the Laver-Shepsle Approach." West European Politics 24 (1): 1-26.

Eurostat. 2019. Eurostat Database. Accessed June 24, 2019. https://ec.europa.eu/eurostat/data/ database.

Gallagher, M. 1991. "Proportionality, Disproportionality and Electoral Systems." Electoral Studies 10: 33-51.

Gemmell, N., et al. 2008. "Foreign Investment, International Trade and the Size and Structure of Public Expenditures." European Journal of Political Economy 24 (1): 151-171.

Giannetti, D., and M. Laver. 2005. "Policy Positions and Jobs in the Government." European Journal of Political Research 44 (1): 91-120.

Hallerberg, M., et al. 2009. Fiscal Governance in Europe. Cambridge: Cambridge University Press.

Hayo, B., and F. Neumeier. 2012. "Leaders' Impact on Public Spending Priorities: The Case of the German Laender." Kyklos 65 (4): 480-511.

Herzog, A., and S. Mikhaylov. 2014. Government in Crisis: Opening the "Black Box" of Intra-cabinet Competition over Budgetary Allocation.

Indiradason, I. H., and G. H. Kristinsson. 2013. "Making Words Count: Coalition Agreements and Cabinet Management." European Journal of Political Research 52: 822-846.

Jochimsen, B., and S. Thomasius. 2014. "The Perfect Finance Minister: Whom to Appoint as Finance Minister to Balance the Budget." European Journal of Political Economy 34: 390-408.

Lasswell, H. D. 1936. Politics: Who Gets What, When, How. New York: Whittlesey House.

Laver, M., and K. A. Shepsle. 1990. "Coalitions and Cabinet Government." American Political Science Review 84 (3): 873-890.

Mahdavi, S. 2004. "Shifts in the Composition of Government Spending in Response to External Debt Burden." World Development 32 (7): 1139-1157.

Martin, L. W., and G. Vanberg. 2014. "Parties and Policymaking in Multiparty Governments: The Legislative Median, Ministerial Autonomy, and the Coalition Compromise." American Journal of Political Science 58 (4): 979-996.

Milesi-Ferretti, G. M., et al. 2002. "Electoral Systems and Public Spending." Quarterly Journal of Economics 117 (2): 609-657.

Nickell, S. 1981. "Biases in Dynamic Models with Fixed Effects." Econometrica 49 (6): 1417-1426.

Niskanen, W. A. 1971. Bureaucracy and Representative Government. Chicago: Aldine.

OECD. 2011. Classification of the Functions of Government. Accessed June 24, 2019. https://www.oecd. org/gov/48250728.pdf.

OECD. 2019. OECD. Stat. Accessed June 24, 2019. https://stats.oecd.org/.

Perotti, R., and Y. Kontopoulos. 2002. "Fragmented Fiscal Policy." Journal of Public Economics 86 (2): 191-222.

Poterba, J. M. 1996. "Do Fiscal Rules Work?" NBER Working Papers April: no. 5550.

Poterba, J. M., and J. von Hagen. 1999. Fiscal Institutions and Fiscal Performance. Chicago: University of Chicago Press.

Potrafke, N. 2011. "Does Government Ideology Influence Budget Composition? Empirical Evidence from OECD Countries." Economics of Governance 12 (2): 101-134.

Raabe, J., and E. Linhart. 2014. "Disentangling the Value of a Ministry: Party Leaders' Evaluations of German State Ministries." West European Politics 37 (5): 1065-1086.

Raudla, R. 2010. "Governing Budgetary Commons: What can We Learn from Elinor Ostrom?" European Journal of Law and Economics 30 (3): 201-221.

Rodrik, D. 1998. "Why do More Open Economies Have Bigger Governments?" Journal of Political Economy 106 (5): 997-1032.

Rose, S. 2006. "Do Fiscal Rules Dampen the Political Business Cycle?" Public Choice 128 (3/4): 407-431. Sanz, I. 2011. "What Do OECD Countries Cut First When Faced with Fiscal Adjustments?" Southern Economic Journal 77 (3): 753-775. 
Sanz, I., and F. G. Velazquez. 2007. "The Role of Aging in the Growth of Government and Social Wefare Spending in the OECD." European Journal of Political Economy 23 (4): 917-931.

Schaltegger, C. A., and L. P. Feld. 2009. "Do Large Cabinets Favour Large Governments? Evidence on the Fiscal Commons Problem for Swiss Cantons." Journal of Public Economics 93 (1-2): 35-47.

Streeck, W. 2014. Buying Time: The Delayed Crisis of Democratic Capitalism. Brooklyn, NY: Verso.

Swank, D. 1988. "The Politicaly Economy of Government Domestic Expenditure in Affluent Democracies, 1960-1980." American Journal of Political Science 32 (4): 1120-1150.

Thies, M. F. 2001. "Keeping Tabs on Partners: The Logic of Delegation in Coalition Governments." American Journal of Political Science 45 (3): 580-598.

Tobrjorn, B., W. C. Muller, and K. Strom. 2005. "Comparative Parliamentary Democracy: a Project Report." European Political Science 4 (1): 42-54.

Tsai, P. 2014. "State Fiscal Rules and Composition Changes in Public Spending Before Election." Public Finance Review 42 (1): 58-91.

Tsebelis, G., and E. C. C. Chang. 2004. "Veto Players and the Structure of Budgets in Advanced Industrialized Countries." European Journal of Political Research 43 (3): 449-476.

Tullock, G., et al. 2002. Government Failure: A Primer in Public Choice. Washington, DC: Cato Institute.

United Nations Statistics Division. 1999. Classifications of the Functions of Government. Accessed June 24, 2019. https://unstats.un.org/unsd/iiss/classification-of-the-functions-of-government-cofog.ashx.

Velasco, A. 2000. "Debts and Deficits with Fragmented Fiscal Policymaking." Journal of Public Economics 76 (1): 105-125.

Vonhagen, J., and I. J. Harden. 1995. "Budget Processes and Commitment to Fiscal Discipline." European Economic Review 39 (3-4): 771-779.

Warwick, P. V. 1999. "Ministerial Autonomy or Ministerial Accommodation? Contested Bases of Government Survival in Parliamentary Democracies." British Journal of Political Science 29: 369-394.

Warwick, P. V., and J. N. Druckman. 2006. “The Portfolio Allocation Paradox: An Investigation Into the Nature of a Very Strong but Puzzling Relationship." European Journal of Political Research 45 (4): 635-665.

Wehner, J. 2010. "Cabinet Structure and Fiscal Policy Outcomes." European Journal of Political Research 49 (5): 631-653.

Wenzelburger, G. 2015. "Parties, Institutions and the Politics of Law and Order: How Political Institutions and Partisan Ideologies Shape Law-and-Order Spending in Twenty Western Industrialized Countries." British Journal of Political Science 45 (3): 663-687.

Zellner, A. 1962. "An Efficient Method of Estimating Seemingly Unrelated Regressions and Tests for Aggregation Bias." Journal of the American Statistical Asssociation 57 (298): 348-368. 